Cuevas-Vargas, H., Fernandez-Escobedo, R., Cortes-Palacios, H., A., \& Ramirez-Lemus, L. (2021). The Relation Between Adoption of Information and Communication Technologies and Marketing Innovation as a Key Strategy to Improve Business Performance. Journal of Competitiveness, 13(2), 23-40. https://doi.org/10.7441/joc.2021.02.02

\title{
The Relation Between Adoption of Information and Communication Technologies and Marketing Innovation as a Key Strategy to Improve Business Performance
}

\author{
- Hector Cuevas-Vargas, Rudy Fernandez-Escobedo, Hector A. Cortes- \\ Palacios, Lidia Ramirez-Lemus
}

\begin{abstract}
Understanding how capacities and resources of companies are crucial factors to improve business performance and competitiveness is a major issue for academics, policy, and decisionmakers. The purpose of this research is to analyze the effects of the adoption of information and communication technologies (ICTs) on marketing innovation as a key strategy to increase the business performance of small- and medium-sized Mexican manufacturing companies. A gap exists in the literature regarding the full understanding of the simultaneous relationship among ICTs, marketing innovation and business performance. For this reason, a quantitative approach and cross-sectional design were applied through Structural Equation Modelling, in which a simple random sampling technique and a self-administered questionnaire was used to gather data from a sample of 230 business owners in the state of Aguascalientes, Mexico. The results indicate that adopting ICTs has a significant influence on marketing innovation. Moreover, marketing innovation showed a considerable impact on business performance. Therefore, decision-makers must pay special attention to the adoption of ICTs, as they are of vital importance for the development of marketing innovations and competitive advantage. Decision-makers must also use their resources and capabilities in innovations that have an impact on the sales strategy, design and promotion of their new products as well as the redesign of existing ones to achieve higher levels of competitiveness.
\end{abstract}

Keywords: adoption of ICTs, marketing innovation, competitiveness, performance, PLS-SEM, SMEs JEL Classification: C38, O32, M31, L25

Received: October, 2020

1st Revision: March, 2021

Accepted: March, 2021

\section{INTRODUCTION}

Understanding capacities and resources of companies as key elements with regard to improving business performance has become an issue of core relevance for directors, consultants and academics. This interest has been focused on specific issues such as Information and 
Communication Technologies (ICTs) and marketing innovation, as both fields seem to have evolved side by side in the last decade to become strategic assets for the improvement of company performance (Cuevas-Vargas et al., 2020; Gargallo Castel \& Galve Gorriz, 2017; Jones et al., 2016; Nieves \& Diaz-Meneses, 2016; Rajapathirana \& Hui, 2018).

In this context, ICTs have served to provide regions and organisations with competitive advantages, which, as well as being sustainable, are capable of generating results faster and more economically (Babkin et al., 2013; Fuks \& Kawa, 2013; Soete, 2006; Volek \& Novotná, 2018). On the other hand, ICTs enable companies to enhance their performance in the market and increase their capacities for growth (Gallegos \& Miralles, 2020; Junge et al., 2016; Na et al., 2019).

Nevertheless, significant gaps exist in the literature in terms of the full understanding of the simultaneous relationship among ICTs, innovation in marketing and business performance. Most studies have been focused on discussing only one or two of these phenomena at a time (Aksoy, 2017; Cuevas-Vargas et al., 2020; Gallegos \& Miralles, 2020; Jones et al., 2016; Junge et al., 2016; Migdadi, 2020). Although other studies have been undertaken that analyze the simultaneous relationship among the variables mentioned above, they have generally neglected marketing component (Grazzi \& Jung, 2016; Rhee \& Stephens, 2020), exploring instead the idea of innovation in a broader sense.

This gap leaves open a large area of opportunity for academics, researchers, consultants, directors, and entrepreneurs to forge a greater understanding of the relationship among these variables correctly. In filling this gap, companies will be enabled to get a firmer grasp on how to develop long term sustainable competitive advantages based on technological and marketing resources, which will translate into better results and performance.

This is particularly relevant for Small- and Medium-Sized Businesses (SMEs) in the Latin American context, as the presence of SMEs across the continent is overwhelming, not to mention the participation in employment and economic growth of these firms. In Mexico, SMEs represent $72 \%$ of jobs and half of the GDP (INEGI, 2019). SMEs also represent economic units under tremendous pressure to develop competitive advantages based on technology and innovation, which will improve their chances of survival in a changing, unstable and adverse global environment (Bianchi et al., 2017; Costa \& Carvalho, 2013).

This empirical study was based on a sample of 230 manufacturing SMEs in the state of Aguascalientes, Mexico. Aguascalientes is home to one of the most dynamic industries in the country as part of the 'Bajío' manufacturing region (the industrial corridor in the center of the country). The region represents 31.7\% of the Mexican Gross Domestic Product (GSP (PIB), with manufacturing having become the main driver of the local economy (Cuevas-Vargas \& CortésPalacios, 2020), contributing a third of the State's GDP. Nevertheless, economic growth has declined due to measures taken against the SARS-CoV-2 (COVID-19) Coronavirus which has caused several businesses to close altogether and has led to the need to find mechanisms to alleviate this situation.

Our research seeks to make a significant contribution to the literature by exploring within the context of Mexican SMEs the simultaneous relationship that exists among the adoption of ICTs, marketing innovation and the performance of the organization, all from the perceptive of the second-generation statistical technique of Structural Equation Modelling (SEM). 
The rest of the article is arranged as follows: in section 2, a review is presented of the empirical and theoretical literature on the relationship among the variables mentioned above, and the research hypotheses is proposed. The methodological structure used to collect and analyse the data is explained in section 3, and section 4 outlines the results obtained and tests the research hypotheses. The theoretical and practical contributions of the findings are discussed in section 5, with Section 6 offering conclusions and implications for future research.

\section{THEORETICAL BACKGROUND}

An organisation's success is determined by its resources, processes and capacities, all of which establish its competitive advantage and progress in a rapidly changing technological environment (Srivastava et al., 2013). Additional elements, such as strategic management and certain microeconomic factors, also contribute to wealth generation within the same organization (Fong Reynoso et al., 2017). In this vein, this research considers ICTs and marketing innovation as core resources and capacities for SMEs performance.

ICTs have a positive impact on an organisation's processes, especially in SMEs (Tung \& Rieck, 2005) since they provide the organisation with tools essential to its operative and strategic enhancement (Okoli et al., 2010). In this way, ICTs have proven to be a source of sustainable competitive advantage, both for individual companies and regions, as they allow better results to be obtained faster and more economically (Babkin et al., 2013; Fuks \& Kawa, 2013; Soete, 2006; Volek \& Novotná, 2018). They also create a collaborative, flexible, and open environment that fosters innovation by (Grazzi \& Jung, 2019; Jasinska \& Jasinski, 2019; Senyo et al., 2019) developing a highly creative and constructive facet of improvement that is reflected in ambits such as the organizational structure and marketing (Cano-Pita \& García-Mendoza, 2018; Scarle et al., 2012).

Moreover, the concept of marketing innovation derives from the idea of innovation applied to the company's marketing mix (Doyle \& Bridgewater, 2017; Matúš et al., 2015): the design of new products, the adoption of recent sales and distribution channels, the creation of new advertising and communication strategies, and the development of new information systems, to mention a few examples.

Marketing innovation enables companies to improve their market share and increase their capacity for growth (Junge et al., 2016), since these factors provide the firms with a sustainable competitive advantage based on an orientation towards their market, improvement in their response capacity to customer needs, and innovation in product development (Gallegos \& Miralles, 2020; Na et al., 2019). In addition, this positive impact has been observed not only in large organizations but has also demonstrated to improve the performance of the SMEs in highly competitive markets (Aksoy, 2017; Medrano et al., 2020; Widtojo et al., 2020).

\subsection{Relationship between ICTs and Marketing Innovation}

The phenomenon of innovation and its relationship with ICTs has been explored extensively (Jasinska \& Jasinski, 2019; Rhee \& Stephens, 2020), all of whom have shown consistent evidence on the positive relationship between market share and the adoption of ICTs in organizations, as 
well as their capacity to innovate. However, the literature on the relationship between ICTs and marketing innovation is scarce, although the positive relationship between the adoption of ICTs and innovation in products was proven more than a decade ago (Gago \& Rubalcaba, 2007). In contrast, these more recent empirical studies have demonstrated that the use of technological platforms and tools to stay close to customers fosters the development of competitive advantages derived from the ability to serve customers' needs quickly (Quaye \& Mensah, 2019).

Case studies, such as the study of the 2012 Olympics in London, have also demonstrated that the use of innovative technology-based communication campaigns and models enable large target audiences to be reached more effectively and efficiently (Santomier et al., 2016). More importantly, Setiowati et al. (2015) demonstrate that, in the context of SMEs, the adoption of ICTs has a positive effect on the capacities of innovation in marketing. Moreover, Mohammadi et al. (2018) explore the effect of ICTs on the elements of the marketing mixes of different organisations, again demonstrating the existence of a positive impact on all the aspects of the mix, including innovative price management.

The first hypothesis of this study is derived from empirical and theoretical evidence collected on the relationship between ICTs and marketing innovation:

H1: The adoption of ICTs has a positive and significant effect on marketing innovation.

\subsection{Relationship between Marketing Innovation and Business Performance}

According to the Oslo Manual Organization for Economic Co-operation and Development (OECD/Eurostat, 2018), marketing innovation refers to the application of new marketing methods including advertising, direct marketing, exhibitions and fairs, market research, and other activities to develop new markets-, new pricing strategies and methods, and sales and after-sales activities. This means that, for an organisation to achieve business success, the development of new marketing techniques, methods and tools is necessary. Therefore, SMEs must constantly seek new and creative solutions to problems and needs in the market to develop new and improved products and strategies continually and thus achieve better levels of competitiveness and increase their business performance (Ungerman et al., 2018).

In this vein, Cuevas-Vargas et al. (2020) found that innovation in marketing is understood as the implementation of new ideas and concepts in the marketing mix, has a positive and significant influence on the performance of SMEs. Moreover, Biégas (2018) found that the development of marketing capacities related to innovation is a positive predictor of the performance of an organisation, the latter being understood from the financial perspective. In the same vein, Ungerman et al. (2018) concluded that a more significant impact of marketing innovation in the context of industry 4.0, the greater the level of business competitiveness would be.

Innovation not only has a positive effect on performance when valued from a general point of view (Gök \& Peker, 2017; Jiménez-Jiménez \& Sanz-Valle, 2011), but also when valued from a marketing point of view. Such innovation helps to improve the development of organisations in the local and international commercial context (Falahat et al., 2020; Zhang \& Zhu, 2016) and forge competitive advantages useful in the context of foreign trade, such as market intelligence, 
product innovation, price setting and communication with customers. Furthermore, Quaye \& Mensah (2019) indicated that marketing innovation is a source of sustainable competitive advantage, which enables organisations to improve their results thanks to more innovative products, more creative promotion activities, the development of more novel sales and distribution channels and differentiated price setting mechanisms (Gök \& Peker, 2020).

The findings mentioned in the preceding paragraphs can be added to those put forward by Setiowati et al. (2015) in their research in which not only did they present the positive effect of ICTs in marketing innovation, but also how the latter generates a positive effect on the results, performance and productivity of organisations. Other authors have explored the same relationship and obtained similar results (Haryanto \& Haryono, 2015; Ho et al., 2018; Junge et al., 2016; Suliyanto et al., 2019). Based on the previous, the second hypothesis of the research is presented as follows:

H2: Marketing innovation has a positive and significant effect on business performance.

\section{RESEARCH OBJECTIVE, METHODOLOGY AND DATA}

Empirical explanatory research was conducted with a causal, non-experimental, transversal and descriptive design and a quantitative approach using the statistical technique known as Partial Least Squares Structural Equation Modelling (PLS-SEM), based on the Smart PLS 3.2.7 statistical software (Ringle et al., 2015). Two steps were followed to do this: first, the measuring modelling is estimated, and then the structural model is evaluated as a hierarchical components model (Becker et al., 2012) using the indicator repetition approach (Cuevas-Vargas et al., 2019; Ringle et al., 2012; Wetzels et al., 2009). This step is necessary to run higher-order models with PLS-SEM through the Smart PLS statistical software (Ringle et al., 2015). The main reason for using this statistical technique is because working with non-parametric tests through bootstrapping solves the potential problems of the lack of normality of the data (Hair et al., 2017).

\subsection{Design of the Sample and the Collection of the Data}

The last complete edition of the National Economic Units' Statistical Directory was taken as a reference for the development of this study (INEGI, 2015), considering the economic units of the manufacturing sector with 11 to 250 employees in the state of Aguascalientes, Mexico, as a population. The directory contains a total of 435 registered small and mediumsized companies; therefore, on selecting the sample with a level of confidence of $95 \%$ and a margin for error of $4.5 \%$, a sample of 228 SMEs was obtained. That is why, by using the simple random sampling technique, looking for maximum consistency between the sample and the directory, the survey was applied from August to November 2015 to owners and managers of the companies selected from the sample, obtaining 230 valid surveys as a result, which represent the sample of the study.

According to the sample distribution, most of the companies surveyed are small, representing $81.7 \%$ of the sample. In terms of the age of the companies, $64.3 \%$ are more than ten years old, $19.6 \%$ are more than five years old, but less than ten, and $16.1 \%$ are less than five years 
old. Also, $75.2 \%$ of the companies are family-owned. The best-represented sectors are agrobusiness with $30.9 \%$, metal mechanics with $18.7 \%$, and textiles with $13.5 \%$, followed by the construction sectors with $11.3 \%$, the furniture industry with $9.1 \%$, the plastics sector with $7 \%$, the electronics industry with $6.1 \%$ and the pharmaceutical industry with only $3.5 \%$.

\subsection{Variables}

\subsubsection{Adoption of ICTs}

To measure the adoption of ICTs, the second-order scale adapted from Chen \& Tsou (2007) was used. This scale measures the adoption of ICTs with four reflective-type dimensions: the infrastructure of ICTs, measured by four indicators; strategic alignment, measured by four indicators; organisational structure, measured by five indicators; and individual learning, measured by five indicators. All these dimensions are measured on the Likert five-point scale, ranging from totally disagree to agree totally.

\subsubsection{Marketing Innovation}

To measure marketing innovation, the reflective type first-order scale used by Cuevas-Vargas et al. (2020) was applied, consisting of nine indicators measured on the Likert five-point scale, ranging from totally disagree to agree totally.

\subsubsection{Performance}

To measure the performance variable, the reflective type first-order scale was used, which considers business performance as a subjective measurement because financial information implies some specific issues to be incurred by SMEs. In this sense, a scale with three indicators that measure economic performance (Tanriverdi, 2006), market share (Chen \& Huang, 2012; Ebrahimi \& Sadeghi, 2013), and productivity (van Hemert et al., 2013) was considered, the indicators are measured by applying the Likert five-point scale, which ranges from totally disagree to agree totally.

\subsection{Reliability and Validity}

To evaluate the reliability and validity of the scales, the measurement model was estimated using the PLS-SEM statistical technique with the Smart PLS 3.2.7 statistical software (Ringle et al., 2015). Based on the results obtained and shown in Table 1, the high internal consistency of all the reflective constructs of the lower and higher order of the measurement model stands out. This is because the composite reliability (CR) exceeds the value of 0.708 recommended by Hair et al. (2017), as well as Cronbach's Alpha, for each one of the constructs is greater than 0.7 (Cuevas-Vargas et al., 2019; Nunnally, 2013). Similarly, the constructs exceed the value of the average variance extracted (AVE) of 0.5 (Fornell \& Larcker, 1981; Hair et al., 2012). Moreover, it has been found that the reliability of the indicator (RI) is greater than 0.5 because its respective standardised factorial loading (SFL) is greater than 0.708 (Hair et al., 2017), and all are statistically significant $(\mathrm{p}<0.001)$. These psychometric tests guarantee the converging reliability and validity of the scales. 
Tab. 1 - Evaluation of the Reflective Type Measurement Model. Source: own research

\begin{tabular}{|c|c|c|c|c|c|c|c|}
\hline \multirow{3}{*}{$\begin{array}{l}\text { First-Order } \\
\text { Constructs } \\
\text { (FOCs) }\end{array}$} & \multirow{3}{*}{ Indicator } & \multicolumn{4}{|c|}{ Convergent Reliability } & \multicolumn{2}{|c|}{$\begin{array}{l}\text { Internal Consistency } \\
\text { Reliability }\end{array}$} \\
\hline & & SFL & RI & $\mathrm{t}$-values & AVE & CR & $\begin{array}{l}\text { Cron- } \\
\text { bach's } \\
\text { Alpha }\end{array}$ \\
\hline & & $>0.708$ & $>0.5$ & $>2.57$ & $>0.5$ & $>0.7$ & $>0.7$ \\
\hline \multirow{4}{*}{$\begin{array}{l}\text { Infra- } \\
\text { structure } \\
\text { of ICTs } \\
\text { (FOC1) }\end{array}$} & ITI1 & 0.941 & 0.885 & 96.897 & \multirow{4}{*}{0.866} & \multirow{4}{*}{0.963} & \multirow{4}{*}{0.948} \\
\hline & ITI2 & 0.939 & 0.881 & 61.624 & & & \\
\hline & ITI3 & 0.935 & 0.874 & 86.402 & & & \\
\hline & ITI4 & 0.907 & 0.822 & 55.230 & & & \\
\hline \multirow{4}{*}{$\begin{array}{l}\text { Strategic } \\
\text { Alignment } \\
\text { (FOC2) }\end{array}$} & AE1 & 0.917 & 0.840 & 59.759 & \multirow{4}{*}{0.866} & \multirow{4}{*}{0.963} & \multirow{4}{*}{0.947} \\
\hline & AE2 & 0.937 & 0.878 & 85.334 & & & \\
\hline & AE3 & 0.931 & 0.866 & 69.326 & & & \\
\hline & AE4 & 0.938 & 0.880 & 73.819 & & & \\
\hline \multirow{5}{*}{$\begin{array}{l}\text { Organi- } \\
\text { sational } \\
\text { Structure } \\
\text { (FOC3) }\end{array}$} & EO1 & 0.925 & 0.855 & 57.686 & \multirow{5}{*}{0.879} & \multirow{5}{*}{0.973} & \multirow{5}{*}{0.966} \\
\hline & $\mathrm{EO} 2$ & 0.931 & 0.866 & 79.092 & & & \\
\hline & EO3 & 0.946 & 0.895 & 115.607 & & & \\
\hline & EO4 & 0.946 & 0.895 & 106.669 & & & \\
\hline & EO5 & 0.940 & 0.883 & 92.332 & & & \\
\hline \multirow{5}{*}{$\begin{array}{l}\text { Individual } \\
\text { Learning } \\
\text { (FOC4) }\end{array}$} & AI1 & 0.915 & 0.837 & 67.444 & \multirow{5}{*}{0.832} & \multirow{5}{*}{0.961} & \multirow{5}{*}{0.949} \\
\hline & AI2 & 0.918 & 0.842 & 51.778 & & & \\
\hline & AI3 & 0.919 & 0.844 & 72.741 & & & \\
\hline & AI4 & 0.924 & 0.853 & 61.069 & & & \\
\hline & AI5 & 0.884 & 0.781 & 40.562 & & & \\
\hline \multirow{8}{*}{$\begin{array}{l}\text { Marketing } \\
\text { Innovation } \\
\text { (FOC5) }\end{array}$} & IMK1 & 0.812 & 0.659 & 26.593 & \multirow{8}{*}{0.614} & \multirow{8}{*}{0.927} & \multirow{8}{*}{0.911} \\
\hline & IMK2 & 0.774 & 0.599 & 21.246 & & & \\
\hline & IMK3 & 0.780 & 0.608 & 20.709 & & & \\
\hline & IMK4 & 0.774 & 0.599 & 22.685 & & & \\
\hline & IMK5 & 0.721 & 0.520 & 17.203 & & & \\
\hline & IMK6 & 0.825 & 0.680 & 30.603 & & & \\
\hline & IMK7 & 0.812 & 0.659 & 28.001 & & & \\
\hline & IMK9 & 0.767 & 0.588 & 23.139 & & & \\
\hline \multirow{3}{*}{$\begin{array}{l}\text { Perfor- } \\
\text { mance } \\
\text { (FOC6) }\end{array}$} & REN1 & 0.903 & 0.815 & 56.311 & \multirow{3}{*}{0.822} & \multirow{3}{*}{0.933} & \multirow{3}{*}{0.891} \\
\hline & REN2 & 0.950 & 0.902 & 111.370 & & & \\
\hline & REN3 & 0.865 & 0.748 & 26.254 & & & \\
\hline
\end{tabular}




\begin{tabular}{|l|l|l|l|l|l|l|}
\hline $\begin{array}{l}\text { Second- } \\
\text { Order Scale }\end{array}$ & $\begin{array}{l}\text { Con- } \\
\text { structs }\end{array}$ & $\begin{array}{l}\text { Path Co- } \\
\text { efficients }\end{array}$ & t-values & AVE & CR & Cronbach's Alpha \\
\hline \multirow{4}{*}{$\begin{array}{l}\text { Adoption } \\
\text { of ICTs }\end{array}$} & FOC1 & 0.817 & 26.636 & & & \\
\cline { 2 - 4 } & FOC2 & 0.906 & 67.135 & \multirow{2}{*}{0.677} & 0.974 & 0.972 \\
\cline { 2 - 4 } & FOC3 & 0.920 & 57.887 & & & \\
\cline { 2 - 4 } & FOC4 & 0.894 & 50.683 & & & \\
\hline
\end{tabular}

In terms of the evidence of the discriminant validity, two tests were applied to guarantee that each latent variable measures what in fact should be measured, which are shown in Table 2. First, the criterion of the Heterotrait-Monotrait ratio (HTMT85) Henseler et al. (2015) is shown above the diagonal on being considered as a criterion of better performance to determine the discriminant validity of the constructs. Also, calculating the complete bootstrapping, the values of the correlations among the reflective constructs were found to be below 0.85 (Henseler et al., 2015; Kline, 2011). The Fornell-Larcker criterion was applied in the same sense, which was determined using the square root of the AVE of each one of the constructs, whose values represent the diagonal of the table, and according to Fornell \& Larcker (1981), these values are greater than their correlations relative to any other construct.

Tab. 2 - Discriminant Validity of First-Order Constructs (FOCs). Source: own research

\begin{tabular}{|l|l|l|l|l|l|l|}
\hline \multirow{2}{*}{$\begin{array}{l}\text { First Order } \\
\text { Construct }\end{array}$ FOCs $)$} & FOC1 & FOC2 & FOC3 & FOC4 & FOC5 & FOC6 \\
\cline { 2 - 7 } & 0.866 & AVE= & AVE= & AVE= & AVE= & AVE= \\
FOC1 & $\mathbf{0 . 9 3 0}$ & 0.866 & 0.879 & 0.832 & 0.614 & 0.822 \\
\hline FOC2 & 0.761 & $\mathbf{0 . 9 3 0}$ & 0.789 & 0.761 & 0.407 & 0.527 \\
\hline FOC3 & 0.636 & 0.755 & $\mathbf{0 . 9 3 8}$ & 0.847 & 0.471 & 0.518 \\
\hline FOC4 & 0.583 & 0.724 & 0.811 & $\mathbf{0 . 9 1 2}$ & 0.410 & 0.464 \\
\hline FOC5 & 0.254 & 0.386 & 0.452 & 0.389 & $\mathbf{0 . 7 8 4}$ & 0.560 \\
\hline FOC6 & 0.423 & 0.483 & 0.482 & 0.428 & 0.518 & $\mathbf{0 . 9 0 7}$ \\
\hline
\end{tabular}

NOTE: The diagonal numbers (in bold) represent the square root of the AVE values. Above the diagonal, the HTMT.85 correlations ratio test is presented; below the diagonal, the Fornell-Larcker criterion test is shown.

Based on these criteria already evaluated, it can be concluded that the data from this study is reliable and valid to test the hypotheses using PLS-SEM.

\section{RESULTS}

First, the descriptive statistics were obtained, which emphasize the manifest variables from each of one of the constructs with which the managers or owners of small and medium-sized companies expressed a greater level of agreement. Concerning the infrastructure of ICTs, it was found that this type of companies has little ICT infrastructure. In recent years, only $30.4 \%$ have placed an emphasis on personal information technology and training, $27.4 \%$ have adopted sophisticated Internet applications, $26.5 \%$ have allocated sufficient budget to the purchase 
of information technology software, and only $25.2 \%$ have allocated adequate funding to the purchase of information technology hardware. In terms of the strategic alignment of ICTs, the study revealed that $40.4 \%$ of companies declare to have implemented their ICT projects following their business strategies in recent years and that their ICT applications have helped their business strategies to improve their products and services offers in recent years. $38.2 \%$ mention that their ICT capacities have helped their business strategies to strengthen their customer service in recent years, and 37.4\% state that their ICT applications have helped their business strategies to improve their process management.

Concerning organisational structure, $44.3 \%$ indicate to have changed their forms by adopting new ICT systems and applications to help managers to make more timely decisions, with more relevance being placed on this variable. Only 34.8\% maintain that they have changed their organisational structure by adopting new ICT systems and applications to improve integration among their different departments. However, the managers of manufacturing SMEs in Aguascalientes consider this variable to be less relevant.

In terms of individual learning, only $38.2 \%$ mention that their employees have been able to learn new ICT applications quickly, 36.5\% indicate that their employees have shown little resistance to the adoption of new ICT systems and applications, 36.1\% claim that they have provided sufficient training on implementing new ICT systems and applications, $34.4 \%$ say that their employees have been able to adopt new ICT systems and applications for their work and $32.6 \%$ mention that their employees have been able to innovate new ideas and approaches to work effectively through the adoption of new ICT systems and applications in recent years. In terms of marketing innovation, the study found that $50 \%$ have introduced significant changes in the form, aspect or taste of products in order to attract new market segments, $47.4 \%$ have developed or adopted new sales methods, either for new or existing products and $45.06 \%$ have modified their packaging to improve their products and make them more attractive. However, only $37.3 \%$ have introduced strategies to drive sales and $34.3 \%$ have introduced new distribution systems.

Concerning companies' performance, $71.3 \%$ have increased their productivity, $65 \%$ consider that their profitability has increased, and $60.4 \%$ believe that their market share has grown.

To test the research hypotheses, the structural model was analysed using bootstrapping applied through Smart PLS 3.2.7 (Ringle et al., 2015). As can be observed in Table 3, there is sufficient evidence to obtain the confidence intervals required to evaluate the accuracy of the parameters. These results show that the structural model has predictive relevance due to that marketing innovation is observed as $18.2 \%$ through the adoption of ICTs (R2 = 0.182). Also, organisational performance is observed as $26.9 \%$ due to marketing innovation $(\mathrm{R} 2=0.269)$. Therefore, the results allow the reader to infer that marketing innovation and organisational performance (endogenous constructs) have an explanatory capacity because the R 2 values are close to and above 0.20 (Chin, 1998; Hair et al., 2017), which indicates that the model has sufficient quality and therefore, its results are useful in business decision-making. 
Tab. 3 - Results of the structural Model with PLS-SEM. Source: own research

\begin{tabular}{|l|l|l|l|l|l|}
\hline Hypotheses & Path & $\begin{array}{l}\text { Standardized } \\
\text { Coefficient } \beta\end{array}$ & t-values & $\mathrm{f}^{2}$ & $\mathrm{R}^{2}$ \\
\hline $\begin{array}{l}\text { H1: The adoption of ICTs has a } \\
\text { positive and significant effect on } \\
\text { marketing innovation }\end{array}$ & $\begin{array}{l}\text { Adoption } \\
\text { of ICTs } \rightarrow \\
\text { Marketing } \\
\text { innovation }\end{array}$ & $0.427^{* * *}$ & 7.169 & 0.223 & 0.182 \\
\hline $\begin{array}{l}\text { H2: Marketing innovation has a } \\
\text { positive and significant effect on } \\
\text { business performance }\end{array}$ & $\begin{array}{l}\text { Marketing } \\
\text { innovation } \\
\text { Performance }\end{array}$ & $0.518^{* * *}$ & 10.775 & 0.367 & 0.269 \\
\hline
\end{tabular}

Significance: $* * *=p<0.001 ; * *=p<0.01 ; *=p<0.05 ;$ NS $=$ Non-significant.

$\mathrm{f}^{2}$ effect sizes: $>0.02=$ small; $>0.15=$ medium; $>0.35=$ large effect (Cohen, 1988).

$\mathrm{R}^{2}$ values: $>0.20$ = weak; $>0.33$ moderate; $>0.67=$ substantial (Chin, 1998).

With regard to the first hypothesis H1, the results obtained and shown in Table $3(\beta=0.427$, $\mathrm{p}<0.001)$ indicate that the adoption of ICTs has positive and significant effects on marketing innovation. Therefore, $\mathrm{H} 1$ is supported because the adoption of ICTs has been found to have an impact of $42.7 \%$ on marketing innovation, and pursuant to the Cohen (1988) test, it is of medium size on having obtained a value of $\mathrm{f}^{2}=0.223$. This value indicates that the adoption of ICTs makes a medium contribution on the power of prediction of marketing innovation of manufacturing SMEs in the state of Aguascalientes. These results confirm the findings of previous studies in different contexts that evidence the positive influence of the adoption of ICTs on the capacities of marketing innovation (Mohammadi et al., 2018; Santomier et al., 2016; Setiowati et al., 2015).

In terms of $\mathrm{H} 2$, the results indicate that marketing innovation has positive and significant effects on the companies' performance $(\beta=0.518, \mathrm{p}<0.001)$. Therefore, $\mathrm{H} 2$ is supported, as marketing innovation has a significant impact of $51.8 \%$ on the performance of SMEs; pursuant to the Cohen (1988) test, it is of medium size, having obtained a value of $\mathrm{f}^{2}=0.367$, which indicates that marketing innovation makes a large contribution to the power of prediction of the performance of manufacturing SMEs in the state of Aguascalientes. In this respect, our findings coincide with those found by Cuevas-Vargas et al. (2020) in their study of SMES in the state of Guanajuato, Mexico which showed that innovation in marketing has a significant effect on business performance. It also corroborates findings in which marketing innovation was demonstrated to both improve the development of companies in the local and international contexts (Falahat et al., 2020; Zhang \& Zhu, 2016) as well as generate sustainable competitive advantages (Quaye \& Mensah, 2019), thus guaranteeing companies better results, performance, and productivity (Setiowati et al., 2015).

\section{DISCUSSION}

Along with supporting the hypotheses put forward, our findings enhance the existing literature in terms of the relationship among the study variables. On the one hand, our results confirm previous findings on the relationship between ICTs and marketing innovation (Gago \& Rubalcaba, 2007; Jasinska \& Jasinski, 2019; Quaye \& Mensah, 2019; Rhee \& Stephens, 2020). In 
this way, the higher the level of ICT adoption, the greater the levels of marketing innovation, an effect which will allow the firm to secure new customers and generate a competitive advantage. This confirms the findings of Rhee \& Stephens (2020) in Korea, and Quaye \& Mensah (2019) in Ghana, with research groups establishing that the absorption of technology improves the capacity for innovation, and the use of ICT generates competitive advantages through cost reduction and the design of new products and processes, all of which are translated into enhanced competition tools for SMEs as compared to more developed companies.

On the other hand, the evidence collected in our study also supports previous studies that emphasize the positive impact of marketing innovation on business performance (Haryanto \& Haryono, 2015; Ho et al., 2018; Junge et al., 2016; Quaye \& Mensah, 2019; Setiowati et al., 2015; Suliyanto et al., 2019; Zhang \& Zhu, 2016). Likewise, the findings are similar to results obtained by Gallegos \& Miralles (2020) in Peru, an emerging economy like Mexico, in which they establish that marketing innovation is a crucial element to achieve a sustainable competitive advantage based on orientation towards the market as well as product development, the latter of which must always grow in collaboration with customers to insure functional coordination between service and user (Na et al., 2019). In the same vein, in their study with Danish firms, Junge et al. (2016) concluded that product and marketing innovation leads to faster productivity growth in skillintensive firms. Nevertheless, the relevance of our research goes beyond merely confirming and enhancing the findings of previous studies. The actual relevance of our research rests on three pillars: its context, scope, and approach.

The first pillar, the context, is based on the fact that the research was conducted in one of the most thriving economic regions in Mexico and was concentrated specifically on the manufacturing SME sector, not only one of the largest generators of employment in the country but one has also become a driver for the economic development of different regions in the country (CuevasVargas \& Cortés-Palacios, 2020; INEGI, 2019).

The second pillar, the scope, is related to the scarcity of literature covering the three variables studied simultaneously, as the majority of studies only cover one or two variables at a time and study innovation in a broader sense (Aksoy, 2017; Cuevas-Vargas et al., 2020; Gallegos \& Miralles, 2020; Grazzi \& Jung, 2016; Jones et al., 2016; Junge et al., 2016; Migdadi, 2020; Rhee \& Stephens, 2020). Thus, by covering the three variables simultaneously, our study contributes to the multi-facet and multi-dimensional phenomena.

The third and last pillar relates to the approach of this study in the discussion of innovation: a good part of the literature explores the phenomenon of innovation from a general point of view (Gök \& Peker, 2017; Jiménez-Jiménez \& Sanz-Valle, 2011). Therefore, the empirical evidence of the study makes an essential contribution to the study of a specific facet of innovation: marketing innovation.

These three pillars make this research a useful tool for:

- Directors, managers, and consultants, as it allows them to validate decisions related to the adoption of ICTs and investments in marketing innovations in their search to develop sustainable competitive advantages (Quaye \& Mensah, 2019; Zhang \& Zhu, 2016) and improve the performance of their business units (Falahat et al., 2020; Gök \& Peker, 2020). 
- Academics, because it enhances the existing literature and opens the door to future studies in other SME sectors in the Mexican and Latin American ambits, of which a contextualized knowledge of the reality of the region is quite lacking, and which is usually worlds apart from the Asian, European and North American facts.

- Public policy makers, since the need to develop public infrastructures that facilitate organizations to adopt ICTs easily and economically is obvious to them. These in turn will become essential sources of innovation in marketing, better business performance, and more significant regional economic development.

\section{CONCLUSION}

The results obtained in this research confirm the positive and significant impact of ICTs on marketing innovation as well as how this type of innovation also has a positive and significant effect on the performance of manufacturing SMEs in an industrial region of a developing country. The study also provides evidence and contributes to reducing the gap that exists in the literature while at the same time enhancing the conclusions of other authors in terms of the subject under study.

Additionally, the research has illustrated the low level of availability and use of ICTs in a web environment, which exposes a significant competitive disadvantage for SMEs. The study has also demonstrated that innovative strategies in advertising, changes in products, and digital platforms (social networks and websites) are necessary to maintain a positive performance in ever more interconnected markets.

SMEs can integrate specific resources and capacities to achieve a competitive advantage by collecting information on potential customers, their expectations and needs, and by using digital marketing tools. Also, the development of innovations that have an impact on the sales strategy, the design and promotion of new products, and the redesign of existing products will achieve a positive effect on the organization's performance.

It seems pertinent, then, to make business people aware of the situation discussed and to encourage them to participate in public and private programs and initiatives to support, develop and use digital tools and to drive innovation in marketing. Hence, the following recommendations can be made to the manufacturing SMEs sector based on our findings: (1) investment in infrastructure and the use ICTs and associating them with the rest of the company's technologies, (2) allocation of resources to the proper education regarding ICTs, (3) introduction of significant changes in the form, aspect or taste of products, (4) adaptation of new sales methods, and (5) improvement and innovation in packaging to make it more attractive to consumers.

Moreover, public policy makers and administrators should develop specific policies to reinforce the link between SMEs and research institutions such as universities to improve the technological, commercial and innovation capacities of organizations. Additionally, becoming involved in these initiatives in other private specialized organizations, such as guilds and specialized consulting firms, may stimulate the transfer of knowledge significantly. 
It is vital to emphasize that the findings of this study have some limitations, as they are based on a sample from 2015 composed of regional SMEs of the manufacturing sector in the state of Aguascalientes. Thus over time there could be a change in the perception of directors concerning ICT infrastructure and individual learning, both key constructs of the adoption of ICT. We suggest therefore replicating the model in other geographical areas that feature different sectors and include organizations of various sizes.

Finally, future research may extend the conclusions of this work with longitudinal studies to determine the causal relationship among the different variables to foster the innovation and development of new products in new companies and adding control variables, such as company age and size. Future lines of research may also analyze the moderating effect of the selection of technology in the relationship between the adoption of ICTs and marketing innovation and how this latter variable affects radical or incremental innovations of products.

\section{References}

1. Aksoy, H. (2017). How do innovation culture, marketing innovation and product innovation affect the market performance of small and medium-sized enterprises (SMEs)? Technology in Society, 51, 133-141. https://doi.org/10.1016/j.techsoc.2017.08.005

2. Babkin, A., Kudryavtseva, T., \& Utkina, S. (2013). Formation of industrial clusters using the method of virtual enterprises. International Conference on Applied Economics (Icoae), 5 (1), 68-72. https://doi.org/10.1016/s2212-5671(13)00011-7

3. Becker, J. M., Klein, K., \& Wetzels, M. (2012). Hierarchical Latent Variable Models in PLSSEM: Guidelines for Using Reflective-Formative Type Models. Long Range Planning, 45 (5-6), 359-394. https://doi.org/10.1016/j.lrp.2012.10.001

4. Bianchi, C., Glavas, C., \& Mathews, S. (2017). SME international performance in Latin America. The role of entrepreneurial and technological capabilities. Journal of Small Business and Enterprise Development, 24 (1), 176-195. https://doi.org/10.1108/JSBED-09-2016-0142

5. Biégas, S. (2018). Marketing Innovation Capacity and Firm Performance in Brazilian Clothing Industries. Revista Brasileira de Estratégia, 11 (3), 343-355. https://doi.org/10.7213/rebrae.11.003. $\mathrm{AO} 03$

6. Cano-Pita, G. E., \& García-Mendoza, M. J. (2018). Las TICs en las empresas: evolución de la tecnología y cambio estructural en las organizaciones. Dominio de Las Ciencias, 4 (1), 499-510. https://doi.org/10.23857/dc.v4i1.762

7. Chen, J. S., \& Tsou, H. T. (2007). Information technology adoption for service innovation practices and competitive advantage. Information Research, 12 (3), 472-477. https://eric. ed.gov/?id=EJ1104803

8. Chen, Y. Y., \& Huang, H.-L. (2012). Knowledge management fit and its implications for business performance: A profile deviation analysis. Knowledge-Based Systems, 27, 262-270. https://doi.org/10.1016/j.knosys.2011.11.012

9. Chin, W. W. (1998). The partial least squares approach to structural equation modeling. In G. A. Marcoulides (Ed.), Modern Methods for Business Research, 295-358. Mahwah, NJ: Lawrence Erlbaum Associates Publishers. 
10. Cohen, J. (1988). Statistical power analysis for the behavioral sciences. Mahwah, NJ: Lawrence Erlbaum Associates Publishers.

11. Costa, T., \& Carvalho, L. (2013). Small and medium enterprises (SME) and competitiveness: an empirical study. In F. Teirlinck, P and Kelchtermans, S and DeBeule (Ed.), Proceedings of the 8th European Conference on Innovation and Entrepreneurship (ECIE 2013), 173-179. Curtis Farm, England: ACAD Conferences LTD.

12. Cuevas-Vargas, H., \& Cortés-Palacios, H. A. (2020). Efectos de la estructura de capital en la innovación. Investigación Administrativa, 49 (126). https://doi.org/10.35426/IAv49n126.02

13. Cuevas-Vargas, H., Parga-Montoya, N., \& Estrada, S. (2020). Incidence of marketing innovation on business performance: an application based on structural equation modeling. Estudios Gerenciales, 36 (154), 66-79. https://doi.org/10.18046/j.estger.2020.154.3475

14. Cuevas-Vargas, H., Parga-Montoya, N., \& Fernández-Escobedo, R. (2019). Effects of Entrepreneurial Orientation on Business Performance: The Mediating Role of Customer Satisfaction-A Formative-Reflective Model Analysis. SAGE Open, 9 (2), 1-14. https://doi. org $/ 10.1177 / 2158244019859088$

15. Doyle, P., \& Bridgewater, S. (2017). Innovation in marketing. Oxford, UK: Taylor \& Francis Group.

16. Ebrahimi, M., \& Sadeghi, M. (2013). Quality management and performance: An annotated review. International Journal of Production Research, 51 (18), 5625-5643. https://doi.org/10.1080/00 207543.2013.793426

17. Falahat, M., Ramayah, T., Soto-Acosta, P., \& Lee, Y. Y. (2020). SMEs internationalization: The role of product innovation, market intelligence, pricing and marketing communication capabilities as drivers of SMEs' international performance. Technological Forecasting and Social Change, 152, 1-7. https://doi.org/10.1016/j.techfore.2020.119908

18. Fong Reynoso, C., Flores Valenzuela, K. E., \& Cardoza Campos, L. M. (2017). La teoría de recursos y capacidades: un análisis bibliométrico. Nova Scientia, 9 (19), 411-440. https://doi. org/10.21640/ns.v9i19.739

19. Fornell, C., \& Larcker, D. F. (1981). Evaluating Structural Equation Models with Unobservable Variables and Measurement Error. Journal of Marketing Research, 18 (1), 39-50. https://doi.org/10.2307/3151312

20. Fuks, K., \& Kawa, A. (2013). e-Sourcing clusters in network economy. In A. Hakansson \& R. Hartung (Eds.), Agent and Multi-Agent Systems in Distributed Systems - Digital Economy and E-Commerce. Studies in Computational Intelligence, 33-51. Berlin- Heidelberg: Springer.

21. Gago, D., \& Rubalcaba, L. (2007). Innovation and ICT in service firms: Towards a multidimensional approach for impact assessment. Journal of Evolutionary Economics, 17 (1), 25-44. https://doi.org/10.1007/s00191-006-0030-8

22. Gallegos, J. F. D. C., \& Miralles, F. (2020). Analyzing marketing innovation in Peruvian manufacturing companies of lower technological intensity. RAE-Revista de Administracao de Empresas, 60 (3), 195-207. https://doi.org/10.1590/S0034-759020200303

23. Gargallo Castel, A. F., \& Galve Gorriz, C. (2017). Family involvement and the impact of information and communication technology on performance. Academia-Revista Latinoamericana 
de Administración, 30 (1), 23-39. https://doi.org/10.1108/ARLA-08-2015-0214

24. Gök, O., \& Peker, S. (2017). Understanding the links among innovation performance, market performance and financial performance. Review of Managerial Science, 11 (3), 605-631. https:// doi.org/10.1007/s11846-016-0198-8

25. Gök, O., \& Peker, S. (2020). The impact of marketing's innovation-related capabilities on a firm's innovation performance. International Journal of Innovation Management, 24 (6). https://doi. org/10.1142/S1363919620500541

26. Grazzi, M., \& Jung, J. (2016). Information and communication technologies, innovation, and productivity: evidence from firms in Latin America and the Caribbean. In M. Grazzi \& C. Pietrobelli (Eds.), Firm Innovation and Productivity in Latin America and the Caribbean. New York: Inter-American Development Bank.

27. Grazzi, M., \& Jung, J. (2019). What are the drivers of ICT diffusion? Evidence from Latin American firms. Information Technologies \& International Development, 15, 34-48.

28. Hair, J. F., Hult, G. T. M., Ringle, C., \& Sarstedt, M. (2017). A primer on partial least squares structural equation modeling (PLS-SEM). Thousand Oaks, CA: SAGE Publications, Inc.

29. Hair, J. F., Sarstedt, M., Ringle, C. M., \& Mena, J. A. (2012). An assessment of the use of partial least squares structural equation modeling in marketing research. Journal of the Academy of Marketing Science, 40 (3), 414-433. https://doi.org/10.1007/s11747-011-0261-6

30. Haryanto, A. T., \& Haryono, T. (2015). The influence of market orientation on innovation type and enterprise performance. Polish Journal of Management Studies, 11 (1), 68-78.

31. Henseler, J., Ringle, C. M., \& Sarstedt, M. (2015). A new criterion for assessing discriminant validity in variance-based structural equation modeling. Journal of the Academy of Marketing Science, 43 (1), 115-135. https://doi.org/10.1007/s11747-014-0403-8

32. Ho, K. L. P., Nguyen, C. N., Adhikari, R., Miles, M. P., \& Bonney, L. (2018). Exploring market orientation, innovation, and financial performance in agricultural value chains in emerging economies. Journal of Innovation and Knowledge, 3 (3), 154-163. https://doi. org/10.1016/j.jik.2017.03.008

33. INEGI. (2019). Censos económicos 2019. Retrieved from https://www.inegi.org.mx/ programas/ce/2019/

34. INEGI. (2015). Directorio Estadístico Nacional de Unidades Económicas. Aguascalientes, Mexico. Retrieved from https://www.inegi.org.mx/app/mapa/denue/default.aspx

35. Jasinska, K., \& Jasinski, B. (2019). Clusters under industry 4.0 conditions - case study: the concept of Industry 4.0 cluster in Poland. Transformations in Business \& Economics, 18 (2), $802-823$.

36. Jiménez-Jiménez, D., \& Sanz-Valle, R. (2011). Innovation, organizational learning, and performance. Journal of Business Research, 64 (4), 408-417. https://doi.org/10.1016/j. jbusres.2010.09.010

37. Jones, C., Motta, J., \& Alderete, M. V. (2016). Strategic management of information and communication technologies and electronic commerce adoption in MSME from Córdoba, Argentine . Estudios Gerenciales, 32 (138), 4-13. https://doi.org/10.1016/j.estger.2015.12.003 
38. Junge, M., Severgnini, B., \& Sorensen, A. (2016). Product-marketing innovation, skills, and firm productivity growth. Review of Income and Wealth, 62 (4), 724-757. https://doi.org/10.1111/ roiw.12192

39. Kline, R. B. (2011). Principles and practice of structural equation modeling. New York, NY: Guilford publications.

40. Matúš, J., Matúšová, J. G., \& Findra, S. (2015). Innovation in marketing - marketing innovation. European Journal of Science and Theology, 11 (6), 147-154.

41. Medrano, N., Cornejo-Canamares, M., \& Olarte-Pascual, C. (2020). The impact of marketing innovation on companies' environmental orientation. Journal of Business \& Industrial Marketing, 35 (1), 1-12. https://doi.org/10.1108/JBIM-10-2018-0319

42. Migdadi, M. M. (2020). Knowledge management, customer relationship management and innovation capabilities. Journal of Business \& Industrial Marketing, 36 (1), 111-124. https://doi. org/10.1108/JBIM-12-2019-0504

43. Mohammadi, R., Lashgarara, F., Najafabadi, M. O., \& Dinpanah, R. (2018). Designing Model of Using Information and Communication Technologies in Rural Marketing Mix of Garmsar County, Iran. Journal of Agricultural Science and Technology, 20 (3), 435-443. http://jast.modares. ac.ir/article-23-19864-en.html

44. Na, Y. K., Kang, S., \& Jeong, H. Y. (2019). The effect of market orientation on performance of sharing economy business: focusing on marketing innovation and sustainable competitive advantage. Sustainability, 11 (3), 1-19. https://doi.org/10.3390/su11030729

45. Nieves, J., \& Diaz-Meneses, G. (2016). Antecedents and outcomes of marketing innovation. An empirical analysis in the hotel industry. International Journal of Contemporary Hospitality Management, 28 (8), 1554-1576. https://doi.org/10.1108/IJCHM-11-2014-0589

46. Nunnally, J. C. (2013). Teoría Psicométrica. Ciudad de México: Trillas.

47. OECD/Eurostat. (2018). Oslo Manual 2018: Guidelines for Collecting, Reporting and Using Data on Innovation. In The Measurement of Scientific; Technological and Innovation Activities (4th ed.). Paris: Paris/Eurostat, Luxembourg. https://doi.org/https://doi. org $/ 10.1787 / 9789264304604-$ en

48. Okoli, C., Mbarika, V. W. A., \& McCoy, S. (2010). The effects of infrastructure and policy on e-business in Latin America and Sub-Saharan Africa. European Journal of Information Systems, 19 (1), 5-20. https://doi.org/10.1057/ejis.2009.48

49. Quaye, D., \& Mensah, I. (2019). Marketing innovation and sustainable competitive advantage of manufacturing SMEs in Ghana. Management Decision, 57 (7), 1535-1553. https://doi. org/10.1108/MD-08-2017-0784

50. Rajapathirana, R. P. J., \& Hui, Y. (2018). Relationship between innovation capability, innovation type, and firm performance. Journal of Innovation and Knowledge, 3 (1), 44-55. https:// doi.org/10.1016/j.jik.2017.06.002

51. Rhee, M., \& Stephens, A. R. (2020). Innovation-orientated technology assimilation strategy and Korean SMEs' enhancing innovation capability, competitive advantage and firm performance. International Journal of Innovation Management, 24 (6). https://doi.org/10.1142/ S1363919620500814 
52. Ringle, C. M., Sarstedt, M., \& Straub, D. W. (2012). A critical look at the use of PLS-SEM in MIS Quarterly. MIS Quarterly, 36 (1), 3-14. https://ssrn.com/abstract=2176426

53. Ringle, C. M., Wende, C. M., \& Becker, J. M. (2015). Smart PLS 3. Boenningstedt: SmartPLS $\mathrm{GmbH}$.

54. Santomier, J. P., Hogan, P. I., \& Kunz, R. (2016). The 2012 London Olympics: innovations in ICT and social media marketing. Innovation: Management, Policy and Practice, 18 (3), 251-269. https://doi.org/10.1080/14479338.2016.1237305

55. Scarle, S., Arnab, S., Dunwell, I., Petridis, P., Protopsaltis, A., \& de Freitas, S. (2012). E-commerce transactions in a virtual environment: virtual transactions. Electronic Commerce Research, 12 (3), 379-407. https://doi.org/10.1007/s10660-012-9098-4

56. Senyo, P. K., Liu, K., \& Effah, J. (2019). Digital business ecosystem: Literature review and a framework for future research. International Journal of Innovation Management, 47, 52-64. https:// doi.org/10.1016/j.ijinfomgt.2019.01.002

57. Setiowati, R., Hartoyo, Daryanto, H. K., \& Arifin, B. (2015). The effects of ICT adoption on marketing capabilities and business performance of Indonesian SMEs in the fashion industry. Journal of Business and Retail Management Research, 10 (1), 100-115.

58. Soete, L. (2006). Information and Communication Technologies and the New Regional Economy. In B. Johansson, C. Karlsson, \& R. Stough (Eds.), The emerging digital economy: Entrepreneurship, clusters, and policy, 5th ed., 21-32. Berlin: Springer-Verlag Berlin Heidelberg. https://doi.org/10.1007/3-540-34488-8

59. Srivastava, M., Franklin, A., \& Martinette, L. (2013). Building a sustainable competitive advantage. Journal of Technology Management and Innovation, 8 (2), 47-60. https://doi.org/10.4067/ s0718-27242013000200004

60. Suliyanto, Novandari, W., \& Suwaryo. (2019). The influence of market orientation on marketing performances in micro small and medium-sized (MSMEs) coconut sugar enterprises: The role of innovation. Quality - Access to Success, 20 (172), 143-147.

61. Tanriverdi, H. (2006). Performance effects of information technology synergies in multibusiness firms. MIS Quarterly: Management Information Systems, 30 (1), 57-77. https://doi. $\operatorname{org} / 10.2307 / 25148717$

62. Tung, L. L., \& Rieck, O. (2005). Adoption of electronic government services among business organizations in Singapore. Journal of Strategic Information Systems, 14 (4), 417-440. https://doi. org/10.1016/j.jsis.2005.06.001

63. Ungerman, O., Dedkova, J., \& Gurinova, K. (2018). The Impact of Marketing Innovation on the Competitiveness of Enterprises in the Context of Industry 4.0. Journal of Competitiveness, 10 (2), 132-148. https://doi.org/10.7441/joc.2018.02.09

64. van Hemert, P., Nijkamp, P., \& Masurel, E. (2013). From innovation to commercialization through networks and agglomerations: Analysis of sources of innovation, innovation capabilities and performance of Dutch SMEs. Annals of Regional Science, 50 (2), 425-452. https://doi.org/10.1007/s00168-012-0509-1 
65. Volek, T., \& Novotná, M. (2018). Labor productivity and technological intensities of small and medium enterprises in manufacturing. In T. Loster, T and Pavelka (Ed.). The 12th International Days of Statistics and Economics, 1884-1893.

66. Wetzels, M., Odekerken-Schröder, G., \& van Oppen, C. (2009). Using PLS Path Modeling for Assessing Hierarchical Construct Models: Guidelines and Empirical Illustration. MIS Quarterly, 33 (1), 177-195. https://doi.org/10.2307/20650284

67. Widtojo, H., Fontana, A., Gayatri, G., \& Soehadi, A. W. (2020). Value co-creation for marketing innovation: a comparative study in the SME community. International Journal of Innovation Management, 24 (3), 2050030. https://doi.org/10.1142/S1363919620500309

68. Zhang, J., \& Zhu, M. (2016). Market orientation, product innovation and export performance: evidence from Chinese manufacturers. Journal of Strategic Marketing, 24 (5), 377-397. https://doi. org/10.1080/0965254X.2015.1052538

\section{Contact information}

Prof. Hector Cuevas-Vargas, Ph.D. - corresponding author

Universidad Tecnológica del Suroeste de Guanajuato

Department of Business Innovation and Marketing

Mexico

E-mail:hcuevas@utsoe.edu.mx

ORCID: 0000-0001-5779-7522

Rudy Fernandez Escobedo, $M B A$

University of the Basque Country/Euskal Herriko Unibertsitatea (UPV/EHU)

Faculty of Economics and Business

Spain

E-mail:rfernandez@rfaconsulting.com.mx

ORCID: 0000-0001-5121-1877

Héctor A. Cortes-Palacios, Ph.D.

Universidad Autónoma de Aguascalientes

Agribusiness Department

Mexico

E-mail:corpal14@hotmail.es

ORCID:0000-0002-4889-5064

Prof. Lidia Ramirez-Lemus

Universidad Tecnológica del Suroeste de Guanajuato

Department of Business Innovation and Marketing

Mexico

E-mail:Iramirez@utsoe.edu.mx

ORCID: 0000-0002-1661-9268 